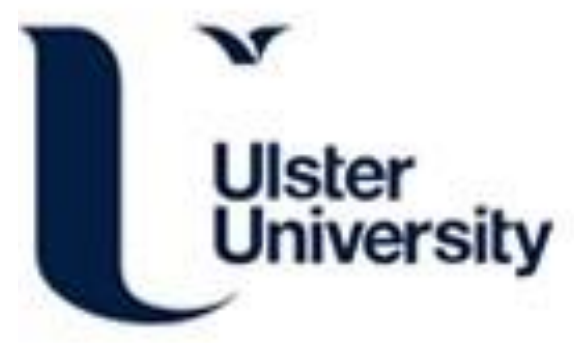

\title{
Longshore size grading on a boulder beach
}

Green, A., Cooper, A., \& Saltzmann, L. (2016). Longshore size grading on a boulder beach. Journal of Sedimentary Research, 86(10), 1123-1128. https://doi.org/10.2110/jsr.2016.71

Link to publication record in Ulster University Research Portal

\section{Published in:}

Journal of Sedimentary Research

\section{Publication Status:}

Published online: 01/10/2016

DOI:

10.2110/jsr.2016.71

\section{Document Version}

Author Accepted version

\section{General rights}

Copyright for the publications made accessible via Ulster University's Research Portal is retained by the author(s) and / or other copyright owners and it is a condition of accessing these publications that users recognise and abide by the legal requirements associated with these rights.

\section{Take down policy}

The Research Portal is Ulster University's institutional repository that provides access to Ulster's research outputs. Every effort has been made to ensure that content in the Research Portal does not infringe any person's rights, or applicable UK laws. If you discover content in the Research Portal that you believe breaches copyright or violates any law, please contact pure-support@ulster.ac.uk. 


\title{
LONGSHORE SIZE GRADING ON A BOULDER BEACH
}

ANDREW GREEN, ANDREW COOPER, AND LESLEE SALZMANN

\begin{abstract}
Longshore size sorting on boulder beaches has not previously been reported. In a boulder beach comprising beachrock slabs, we report systematic longshore clast size grading. The boulder beach at Mission Rocks, South Africa is deposited on an elevated (b3 m MSL) shore platform and comprises imbricated clasts up to $5 \mathrm{~m}$ in the a-axis dimension ( 9 tonnes). The clasts are derived from adjacent intertidal beachrock and eolianite outcrops and are emplaced during high-magnitude wave events. Four distinct downdrift-fining cells are present. Each is 40-50 m long.
\end{abstract}

The sorting is attributed to post-emplacement clast redistribution in which the smallest clasts are transported most frequently (by lower-magnitude storms) and therefore travel farthest downdrift. The updrift cell boundary is marked by boulders ( $5 \mathrm{~m}$ in length) that exceed the transport threshold for all but the most energetic of storms while the downdrift limit contains clasts $0.3 \mathrm{~m}$ in length. This mechanism of longshore size sorting does not rely on variations in longshore wave power as does cell development on sand and gravel beaches. The alongshore sorting via multiple high- (and variable-) magnitude events over a period of time, distinguishes these coarse clast deposits from those of single extreme events (whether storms or tsunamis).

\section{INTRODUCTION}

The longshore sorting of beach sediment by waves has received much attention. On sand and gravel beaches longshore sorting is manifest in variability of size (Komar 1977; Stapor and May 1983) and shape (Bluck 1967; Carr 1969; Carr 1971; Illenberger 1991) and may also be reflected in heavymineral distributions (Frihy and Komar 1991; Li and Komar 1992; Frihy and Lotfy 1997). The concept of littoral power gradient (Stapor 1971; May and Tanner 1973) identified zones of source, transport, and deposition based on alongshore variability of wave energy on sand and gravel beaches. In response to such variability, beaches tend to move toward equilibrium through changes in the shoreline position and/or alongshore sorting of sediment. The resulting beach equilibrium forms have been identified on sand and gravel beaches (e.g., Carter and Orford 1993) and have been classified as swash-aligned, drift-aligned, and size graded (Carter 2002) or static, metastable, and dynamic (Woodroffe 2002). Boulder beaches (e.g., Oak 1985; McKenna 2005) are fundamentally different from their finer-grained sand and gravel counterparts (Buscombe and Masselink 2006). They have a high transport threshold (limited to extreme wave conditions) and limited post-storm recovery such that their profile shape has traditionally been regarded as reflecting the most recent or biggest storm (Oak 1981, 1985). Their cross-shore gradient is thus progressively reduced by successive major storms as they equilibrate with wave conditions: smaller subsequent storms have little impact. The cross-shore size sorting on boulder beaches (fining landwards) is a reflection of the landward reduction in wave energy. Despite recognition of cross-beach size variability (Oak 1985) longshore variability has not been reported, and Waag and Ogren (1984) explicitly dismiss any form of longshore organization of boulder beaches. 
At Mission Rocks (Fig. 1), a rocky coastline on the subtropical, highenergy east coast of South Africa, a boulder beach comprising slabs of beachrock is present on a $\mathrm{p} 3 \mathrm{~m}$ raised shore platform (Salzmann and Green 2012). In this paper, we describe longshore variability of boulder size (expressed as mass) and cell development in the boulder beach and discuss the formative processes.

\section{Coastal Physiography and Wave Climate}

The coastline at Mission Rocks is straight, with minor crenulations and is orientated NNE-SSW (Fig. 1). Offshore, the shelf is narrow (4 km) (Green 2009) and the coastline is wave-dominated (Smith et al. 2010). Waves generally approach from S to SE (Fig. 1) (Smith et al. 2010) and produce a net northward littoral transport (Birch 1996). The largest measured swells (1979-2009) are Hso $1 / 49 \mathrm{~m}$ for Tropical Storm Imboa (1984) (Guastella and Rossouw 2009) and Hso $1 / 48.5 \mathrm{~m}$ for the March (2007) Cut-Off-Low (CoL) swell (Fig. 2). The Hmax for tropical storm Imboa and the March (2007) CoL swell were $14 \mathrm{~m}$ and $15 \mathrm{~m}$, respectively. Numerically modeled wave heights based on boulder sizes at Mission Rocks indicate that the largest measured boulder was emplaced by a storm wave with an Hs of 11.36 m (Salzmann and Green 2012).

\section{METHODS}

Boulders were measured on the basis of their A, B, and C axes. Longaxis orientations, geometries, and surface appearances were also recorded. A total of 134 boulders were measured and their positions were mapped onto an orthophotograph using a grid system. Size attributes (portrayed as mass) were contoured using the Kriging option in the Golden Software package Surfer, with a grid cell size of $0.5 \mathrm{~m} 30.5 \mathrm{~m}$. This was in order to depict spatial trends in boulder size distribution. Critical wave heights associated with transport of these boulders were calculated using equations in Pignatelli et al. (2009). These equations were used by Salzmann and Green (2012) to account for the initial emplacement of the boulder beach. In this paper all threshold transport values for postemplacement reworking are based on a subaerial pre-transport setting due to their loose arrangement on the shore platform. As such we employ the following equations of Pignatelli et al. (2009) for a subaerial setting:

$$
H_{\text {scrit }}=\frac{\left[2\left(\rho_{s}-\rho_{w} / \rho_{w}\right) b^{2} c g-4 C_{m} b c^{2} \ddot{u}\right]}{\left[g\left(C_{d} c^{2}+C_{l} b^{2}\right)\right]} .
$$

Where:

Hscrit: critical height of storm wave at breaking point $(m)$

a: length of the longest boulder axis $(\mathrm{m})$

$\mathrm{b}$ : length of the intermediate boulder axis $(\mathrm{m})$

c: length of the shortest boulder axis $(\mathrm{m})$

Cd: coefficient of drag (Cd 1/4 2 in Pignatelli et al.'s (2009) equations) 
$\mathrm{Cm}$ : coefficient of mass $(\mathrm{Cm} 1 / 41)$

Cl: coefficient of lift (Cl 1⁄4 0.178 in Pignatelli et al.'s (2009) equations)

g: gravitational acceleration (9.8m.s 1$)$

qw: density of water (taken as $1.02 \mathrm{~g} . \mathrm{cm} 1$ )

qs: representative saturated density of beachrock in the locality $(2.1 \mathrm{~g} . \mathrm{cm} 3)$

"u: instantaneous acceleration of flow ( "u $1 / 1 / 4$ m.s 2$)$

Furthermore, as Salzmann and Green (2012) explicitly dismiss a tsunamigenic origin for the boulders, we consequently focus only on the hydrodynamics of storm-wave modeling (Hs).

\section{RESULTS}

\section{Boulder Beach Morphology and Texture}

A 1-km-long stretch of coast at Mission Rocks is composed of fine-to medium-grained sand eolianite with isolated lenses of conglomeratic beachrock backed by a high, vegetated sand dune. A gently seawardsloping shore-platform is cut into these lithologies at mean sea level (MSL), and a flatter raisedp3 $\mathrm{m} \mathrm{MSL}$ platform is also present. The lower shore platform varies from 5 to $20 \mathrm{~m}$ in width, with the width of the raised platform varying between $0 \mathrm{~m}$ and $10 \mathrm{~m}$.

The boulders occur as a 2-10-m-wide beach of large clasts resting on the higher platform and abutting the dune cordon (Fig. 3A). The seaward edge of the platform is devoid of boulders, and the greatest accumulation of boulders occurs at the landward edge of the platform. This forms a narrow boulder beach that is less than $3 \mathrm{~m}$ thick (Fig. 3A). It comprises predominantly slabby boulders of eolianite that are constrained in size by original bedding thickness (, $1 \mathrm{~m}$ ) and the dominant joint sets of the area (1-4 $\mathrm{m}$ spacing in the $\mathrm{a}$ and $\mathrm{b}$ axis planes) (Fig. 3B). Fresh dislocation slots in the surface of the raised platform (Fig. 3B), and fresh abrasion surfaces on several boulders (Fig. 3C) attest to recent reworking of the boulder beach (Fig. $3 \mathrm{C}$ ).

The boulders show a dominant alongshore imbrication, consistent with the net littoral drift direction (Fig. 3A). Clasts were all slabby, and there was no longshore or cross-shore variability in shape. There was no crossshore variability in size, but four crude down-drift-fining cells are evident alongshore, each of which is $\sim 40 \mathrm{~m}$ long (Fig. 4A, B). Each cell is bounded on the updrift side by clasts of . 5 tonnes, and the size reduces progressively downdrift to an average size of , 2 tonnes. Calculated wave heights required to transport the largest clasts from a subaerial setting were $3.8 \mathrm{~m}$ (Table 1), while the smaller (, 2 tonnes) clasts could be transported in a subaerial setting by waves with an Hs in the range of greater than $1 \mathrm{~m}$ for the smallest clasts (Table 2).

\section{DISCUSSION}

The emplacement of boulders on the shoreline has been described in a variety of settings, either as individual forms or as small groups of boulders (Hansom and Hall 2009) or in boulder beaches (Oak 1984; McKenna 2006) and ridges (Etienne and Paris 2010). While cross-shore size and shape 
variability is well known, the apparent longshore size grading described here has not previously been documented for boulder beaches.

Longshore sorting on sand and gravel beaches often reflects achievement of equilibrium between wave energy and grain size (Carter 2002). Such a mechanism is not plausible for development of longshore sorting in boulder beaches in a single event because of the short duration of transportcapable extreme events and the short $(50 \mathrm{~m})$ source-sink distance. Below we consider the cumulative effect of several events of varying intensity and recurrence interval.

The general fabric and structure of the boulder beach at Mission Rocks is interpreted as a result of initial deposition of boulders of a range of sizes ( 0.8 to 9.0 tonnes), and their subsequent reorganization into cell-like structures similar to those found on gravel and sand beaches. The clasts are liberated from intertidal source areas and deposited on an elevated shore platform by the highest-magnitude storm waves (Salzmann and Green 2012). Due to the very high energy levels of emplacement (well above the critical threshold for movement), the initial boulder beach is sensitive only to size in the cross-shore upslope dimension. Transport and emplacement is insensitive to shape in any dimension. As a result, no initial longshore sorting by either size or shape occurs. Longshore sorting of boulders must therefore be a post-emplacement phenomenon, attributed to subsequent size sorting of the boulders during multiple, post-emplacement, lower-energy (but still extreme) events.

The largest of the clasts emplaced during the highest-magnitude storms (calculations suggest Hs $>11$ $\mathrm{m}$ ) resist subsequent reorganization as their sizes are above the threshold for transport by all but the largest storms (Hs $>3.8 \mathrm{~m}$ ). These become the updrift cell boundaries. In the lee of these large clasts, however, smaller clasts are moved downdrift by lowermagnitude storm events (Hs , 3 m; Table 1). The finest material is preferentially entrained (transport-capable storms occur more frequently) and travels farthest downdrift during the event. The calculations suggest that transportcapable waves for the finer boulder clasts include several historical storms (Fig. 2). The sorting mechanism involves smaller clasts travelling downdrift until they come to rest when the transporting flow velocity drops below threshold for that clast (when the storm wanes). The northward-fining pockets indicate a dominant south to north transport continuum that is consistent with the dominant wave direction. We consider that the formation of cell morphology occurs in stages. During the intervening fair-weather periods when wave activity is below the threshold of movement for the smaller boulders, no process is in operation that can reverse this tendency towards downdrift fining. Once the next competent storm occurs, the process of down-drift fining is resumed from the point where the previous event stopped. The number of intervening years has little effect on the overall process.

We do not exclude the possibility that new clasts may be emplaced during lower-energy events, but these too would eventually be sorted alongshore. The supply of new clasts to the beach is, however, limited: the intertidal platform is devoid of loose blocks and no new cementation is occurring in the source area that would replenish material quarried.

Similarly, it is possible that, once emplaced, the largest clasts may act like headlands and create wave-sheltered conditions in their lee. Such a situation was noted on the boulder beaches of the embayed north coast of Northern Ireland where boulders were bigger on the wave-exposed westfacing ends of boulder-beach embayments (McKenna 1990). 
Recognition that the mechanism of longshore sorting is the combined effect of multiple highmagnitude wave events over a considerable time period has important implications for the interpretation of such deposits both on contemporary coasts and in the geological record. Our observations imply repeated cycles of storm waves, with varying recurrence intervals that rework the beach to create the size sorting trends. This differentiates them from deposits associated with single, extreme events (either storm or tsunami). The latter are typically poorly sorted as all competent clasts are moved during the event.

\section{CONCLUSIONS}

Systematic alongshore variability in boulder-beach deposits is reported here for the first time and interpreted as the result of initial emplacement and subsequent sorting during lower-energy but still extreme events. The 40-m-long downdrift fining units are not related to longshore variations in wave energy but to unidirectional longshore transport of finer boulders during multiple events. The cell boundaries are dictated by the location of the largest boulders. Selective transport of the finer clasts takes place in accordance with their size (lesser storms occur more frequently and so smaller clasts move more frequently). Occasional new clasts are introduced during extreme wave events, though these too are sorted eventually. Alongshore sorting in boulder beaches via multiple high- (and variable-) magnitude events over a period of time distinguishes these coarse-clast deposits from those of single extreme events.

\section{ACKNOWLEDGMENTS}

We acknowledge the National Ports Authority for permission to publish the wave data depicted in Figures 1 and 2 and the iSimangaliso Wetland Park for permission to work in the area. Thoughtful reviews by Dr. Daniel Buscombe and an anonymous reviewer aided in the clarity of the final paper. AG acknowledges a young geomorphologist grant by the International Association of Geomorphologists to present this work at the 8th IAG in Paris. The University of KwaZulu-Natal is similarly acknowledged for provision of matching conference funding.

\section{REFERENCES}

BIRCH, G.F., 1996, Unconsolidated sediments on the eastern margin of South Africa (Cape Padrone to Cape Vidal): Geological Survey of South Africa, Bulletin, v. 118, 58 p.

BLUCK, B.J., 1967, Sedimentation of beach gravels: examples from South Wales: Journal of Sedimentary Petrology, v. 37, p. 128-156.

BUSCOMBE, D., AND MASSELINK, G., 2006, Concepts in gravel beach dynamics: EarthScience Reviews, v. 79, p. 33-52.

CARR, A.P., 1969, Size grading along a pebble beach: Chesil Beach, England: Journal of Sedimentary Petrology, v. 39, p. 297-311. 
CARR, A.P., 1971, Experiments on longshore transport and sorting of pebbles: Chesil Beach, England: Journal of Sedimentary Petrology, v. 41, p. 1084-1104.

CARTER, R.W.G., 2002, Coastal Environments: An Introduction to the Physical, Ecological and Cultural Systems of Coastline: London, Elsevier, $617 \mathrm{p.}$

CARTER, R.W.G., AND ORFORD, J.D., 1993, The morphodynamics of coarse clastic beaches and barriers: a short- and long-term perspective: Journal of Coastal Research, v. 15, p. 158-179.

ETIENNE, S., AND PARIS, R., 2010, Boulder accumulations related to storms on the south coast of the Reykjanes Peninsula (Iceland): Geomorphology, v. 114, p. 55-70.

FRIHY, O.E., AND KOMAR, P.D., 1991, Patterns of beach-sand sorting and shoreline erosion on the Nile Delta: Journal of Sedimentary Petrology, v. 61, p. 544-550.

FRIHY, O.E., AND LOTFY, M.F., 1997, Shoreline changes and beach-sand sorting along the northern Sinai coast of Egypt: Geo-Marine Letters, v. 17, p. 140-146.

GREEN, A.N., 2009, Sediment dynamics on the narrow, canyon-incised and current swept shelf of the northern KwaZulu-Natal continental shelf, South Africa: Geo-Marine Letters, v. 29, p. 201-219.

GUASTELLA, L.A., AND ROSSOUW, M., 2009, Coastal vulnerability: are coastal storms increasing in frequency and intensity along the South African coast?: Reef Journal, v. 2, p. 129-139.

HANSOM, J.D., AND HALL, A.M., Magnitude and frequency of extra-tropical North Atlantic cyclones: a chronology from cliff-top storm deposits: Quaternary International, v. 195, p. $42-52$.

ILLENBERGER, W.K., 1991, Pebble shape (and size!): Journal of Sedimentary Petrology, v. 61, p. $756-767$.

KOMAR, P.D., 1977, Selective longshore transport rates of different grain-size fractions within a beach: Journal of Sedimentary Petrology, v. 47, p. 1444-1453.

LI, M.Z., AND KOMAR, P.D., 1992, Longshore grain sorting and beach placer formation 
adjacent to the Columbia River: Journal of Sedimentary Petrology, v. 62, p. 429-441. MAY, J.P., AND TANNER, W.F., 1973, The littoral power gradient and shoreline changes, in Coates, D.R., ed., Coastal Geomorphology: State University of New York, Binghamton, p. 44-60.

MCKENNA, J., 1990, Morphodynamics and Sediments of Basalt Shore Platforms [Unpublished Ph.D. thesis]: University of Ulster, Coleraine, 2 volumes. MCKENNA, J., 2005, Boulder Beaches, in Schwartz, M., ed., Encyclopedia of Coastal Systems: Berlin, Kluwer, p. 206-208.

OAK, H.L., 1981, Boulder beaches: a sedimentological study [Ph.D. Thesis]: Macquarie University, School of Earth Sciences, 272 p.

OAK, H.L., 1985, Process inference from coastal-protection structures of boulder beaches: Geografiska Annaler, Series A, v. 68, p. 25-31.

PIGNATELLI, C., SANSO, P., AND MASTRONUZZI, G., 2009, Evaluation of tsunami flooding using geomorphologic evidence: Marine Geology, v. 260, p. 6-18.

SALZMANN, L., AND GREEN, A.N., 2012, Boulder emplacement on a tectonically stable, wave-dominated coastline, Mission Rocks, northern KwaZulu-Natal, South Africa: Marine Geology, v. 323, p. 95-106.

SMITH, A.M., MATHER, A.A., BUNDY, S.C., COOPER, J.A.G., GUASTELLA, L.A., RAMSAY, P.J., AND THERON, A.K., 2010, Contrasting styles of swell-driven coastal erosion: examples from KwaZulu-Natal, South Africa: Geological Magazine, v. 147, p. 940-953. STAPOR, F.W., 1971, Sediment budgets on a compartmentalised low-to-moderate energy coast in northwest Florida: Marine Geology, v. 10, p. 1-7.

STAPOR, F.W., AND MAY, J.P., 1983, The cellular nature of littoral drift along the northeast Florida coast: Marine Geology, v. 51, p. 217-237.

WAAG, C.J., AND OGREN, D.E., 1984, Shape evolution and fabric in a boulder beach, Monument Cove, Maine: Journal of Sedimentary Petrology, v. 54, p. 98-102. WOODROFFE, C.D., 2002, Coasts: Cambridge, UK, Cambridge University Press, 623 p. 


\begin{tabular}{|c|c|c|c|c|c|c|}
\hline \multirow[b]{2}{*}{ Boulder } & \multicolumn{3}{|c|}{ Axer (m) } & \multirow[b]{2}{*}{ Adjusted V(m²) } & \multirow[b]{2}{*}{ Adjusted Mass (t) } & \multirow{2}{*}{$\begin{array}{c}\mathrm{H}_{\mathrm{sen}} \geq \\
\mathrm{s}_{\mathrm{a}} \mathrm{z}\end{array}$} \\
\hline & $A$ & B & c & & & \\
\hline 4 & 4.93 & 25 & 0.39 & 4.81 & 10.57 & 3.80 \\
\hline 17 & 5.45 & 226 & 0.35 & 4.31 & 9.48 & 3.42 \\
\hline 8 & 3.08 & 3.03 & 0.44 & 4.11 & 9.03 & 4.42 \\
\hline 1 & 2.7 & 2.12 & 0.7 & 4.01 & 8.81 & 3.78 \\
\hline 22 & 2.99 & 1.77 & 0.64 & 339 & 7.45 & 3.09 \\
\hline 8 & 4.22 & 302 & 0.23 & 2.93 & 6.45 & 2.72 \\
\hline 29 & 4.26 & 2.51 & 0.27 & 2.89 & 635 & 2.99 \\
\hline 38 & 1.84 & 1.67 & 0.83 & 2.55 & 5.61 & 2.56 \\
\hline 37 & 284 & 1.97 & 0.41 & 2.29 & 5.05 & 3.39 \\
\hline
\end{tabular}

TABLE 1.-Large boulder (. $5 \mathrm{t}$ ) attributes with corresponding Hs estimates using Pignatelli et al.'s (2009) equations. Data of significance in the text refers to the subaerial blocks shifted by storm waves. Sa $=$ subaerial setting.

\begin{tabular}{|c|c|c|c|c|c|c|c|c|c|c|c|c|c|}
\hline \multirow[b]{2}{*}{ Bealder } & \multicolumn{3}{|c|}{ Axes (m) } & \multirow[b]{2}{*}{ Adjustod $V\left(m^{2}\right)$} & \multirow[b]{2}{*}{ Adjusted Mass (t) } & \multirow{2}{*}{$\begin{array}{c}\mathrm{H}_{\mathrm{asa}} \geq \\
\mathrm{S}\end{array}$} & & & & & & & \\
\hline & 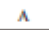 & B & c & & & & & & & & & & \\
\hline 8 & 1.87 & 1.79 & 0.27 & 0.90 & 1.99 & 2.67 & & & & & & & \\
\hline 55 & 1.79 & 1.61 & 0.31 & 0.89 & 1.97 & 270 & & & & & & & \\
\hline 29 & 1.74 & 1.55 & 0.33 & 0.89 & 1.96 & 268 & & & & & & & \\
\hline 44 & 1.62 & 1.2 & 0.45 & 0.87 & 1.92 & 208 & & & & & & & \\
\hline 28 & 1.62 & 1.12 & 0.48 & 0.87 & 1.92 & 1.85 & & & & & & & \\
\hline 45 & 263 & 1.72 & 0.19 & 0.86 & 1.89 & 209 & & & & & & & \\
\hline 19 & 2.15 & 1.65 & 0.24 & 0.85 & 187 & 241 & & & & & & & \\
\hline 14 & 1.83 & 1.44 & 0.32 & 0.84 & 1.86 & 252 & & & & & & & \\
\hline 13 & 3.11 & 15 & 0.18 & os4 & 1.85 & 1.93 & & & & & & & \\
\hline 35 & 23 & 1.43 & 0.25 & 0.82 & 1.81 & 230 & & & & & & & \\
\hline 17 & 238 & 1.63 & 0.21 & 0.81 & 1.79 & 221 & & & & & & & \\
\hline 18 & 1.63 & 1.78 & 0.28 & 0.81 & 1.79 & $2 \pi 2$ & & & & & & & \\
\hline 21 & 201 & 1.68 & 0.24 & 0.81 & 1.78 & 243 & & & & & & & \\
\hline 40 & 2.1 & 133 & 0.29 & 0.81 & 1.78 & 232 & & & & & & & \\
\hline 27 & 1.58 & 1.31 & 0.39 & 0.81 & 1.78 & 236 & & & & & & & \\
\hline 48 & 244 & 132 & 0.25 & 0.81 & i. $n$ & 220 & & & & & & & \\
\hline 22 & 204 & 1.03 & 0.38 & 0.80 & 1.76 & 1.79 & & & & & & & \\
\hline 24 & 208 & 1.42 & 0.27 & 0.80 & 1.75 & 237 & & & & & & & \\
\hline 16 & 1.95 & $1 . n$ & 0.23 & 0.79 & 1.75 & 241 & & & & & & & \\
\hline 24 & 1.84 & 1.05 & 0.41 & 0.79 & 1.74 & 1.79 & & & & & & & \\
\hline 25 & 205 & 1.43 & 0.27 & 0.79 & 1.74 & 238 & & & & & & & \\
\hline 28 & 1.95 & 1.44 & 0.28 & 0.79 & 1.73 & 2.42 & & & & & & & \\
\hline 26 & 1.49 & 139 & 0.37 & an & 1.69 & 250 & & & & & & & \\
\hline 30 & 1.77 & 0.86 & 0.5 & 0.76 & 1.67 & 1.19 & & & & & & & \\
\hline 16 & 204 & 1.69 & 0.22 & 0.76 & 1.67 & 230 & & & & & & & \\
\hline 38 & 1.92 & 2.18 & 0.18 & 0.75 & 1.66 & 2.10 & & & & & & & \\
\hline 37 & 137 & 0.88 & 0.62 & 0.75 & 1.64 & 1.05 & & & & & & & \\
\hline 15 & 2.17 & 1.86 & 0.18 & 0.73 & 1.60 & 204 & & & & & & & \\
\hline 37 & 1.79 & 1.19 & 0.34 & a.n & 159 & 2.15 & & & & & & & \\
\hline 25 & 24 & 1.16 & 0.26 & 0.72 & 159 & 204 & & & & & & & \\
\hline 14 & 134 & 1.36 & 0.39 & 0.71 & 156 & 245 & & & & & & & \\
\hline 11 & 1.56 & 1.08 & 0.41 & 0.69 & 152 & 1.86 & & & & & & & \\
\hline 15 & 1.77 & 1.21 & 0.32 & 0.69 & 151 & 2.18 & & & & & & & \\
\hline 23 & 1.96 & 139 & 0.25 & 0.68 & 150 & 226 & & & & & & & \\
\hline 39 & 1.98 & 1.63 & 0.21 & 0.68 & 1.49 & 221 & & & & & & & \\
\hline 24 & 24 & 1.12 & 0.25 & 0.67 & 1.48 & 1.96 & & & & & & & \\
\hline 3 & 1.62 & 1.53 & 0.27 & 0.67 & 1.47 & 247 & & & & & & & \\
\hline 50 & 2.18 & 1.45 & 0.21 & 0.66 & 1.46 & 2.11 & & & & & & & \\
\hline 23 & 1.66 & 1.14 & 0.34 & 0.64 & 1.42 & 205 & & & & & & & \\
\hline 7 & 22 & 1.21 & 0.24 & 0.64 & 1.41 & 205 & & & & & & & \\
\hline 17 & 1.66 & 1.53 & 0.25 & 0.63 & 1.40 & 238 & & & & & & & \\
\hline 14 & 1.94 & 1.55 & 0.21 & 0.63 & 139 & 2.17 & & & & & & & \\
\hline 43 & 1.63 & 1.22 & 0.31 & 0.62 & 136 & 2.19 & & & & & & & \\
\hline 27 & 235 & 1.44 & 0.18 & 0.61 & 134 & 1.91 & & & & & & & \\
\hline 42 & 1.82 & 1.27 & 0.26 & 0.60 & 132 & 2.17 & & & & & & & \\
\hline 1 & 1.69 & 1.6 & 0.22 & 0.59 & 131 & 226 & & & & & & & \\
\hline 9 & 2.11 & 1.55 & 0.18 & 0.59 & 130 & 1.95 & & & & & & & \\
\hline 3 & 206 & 1.27 & 0.22 & 0.58 & 1.27 & 203 & & & & & & & \\
\hline 11 & 225 & 1.21 & 0.21 & 0.57 & 1.26 & 1.94 & & & & & & & \\
\hline 30 & 1.56 & 1.03 & 0.35 & 0.56 & 1.24 & 1.83 & & & Axes (n & & & & \\
\hline 2 & 15 & 0.95 & 0.37 & 0.53 & 1.16 & 1.62 & & & & & & & $\mathrm{H}_{\mathrm{sent} \text { ? }}$ ? \\
\hline 21 & 2.15 & 1.74 & 0.14 & 0.52 & 1.15 & 1.64 & Boulda & A & B & c & Adjunted $V\left(m^{3}\right)$ & Adjuted Mass (t) & $\mathrm{s}_{\mathrm{s}}$ \\
\hline 10 & 1.58 & 1.43 & 0.23 & 0.52 & 1.14 & 221 & & & & & & & \\
\hline 10 & 1.7 & 0.88 & 0.34 & 0.51 & 1.12 & 1.51 & 13 & 1.56 & 1.1 & 0.24 & 0.41 & 0.91 & 1.92 \\
\hline 29 & 1.51 & 1.11 & 0.3 & 0.50 & 1.11 & 200 & 19 & 226 & 1.25 & 0.14 & 0.40 & 0.87 & 1.53 \\
\hline 12 & 1.77 & 1.4 & 0.2 & 0.50 & 1.09 & 202 & $\begin{array}{l}19 \\
36\end{array}$ & $\begin{array}{l}2.26 \\
0.98\end{array}$ & 1.69 & 0.22 & 0.36 & 0.80 & 230 \\
\hline $\begin{array}{l}20 \\
13\end{array}$ & $\begin{array}{l}1.74 \\
168\end{array}$ & $\begin{array}{l}1.11 \\
152\end{array}$ & 0.25 & $\begin{array}{l}0.48 \\
0.43\end{array}$ & $\begin{array}{l}1.06 \\
0.96\end{array}$ & 1.95 & 16 & 1.95 & 0.96 & 0.18 & 0.34 & 0.74 & 1.59 \\
\hline $\begin{array}{r}13 \\
6\end{array}$ & $\begin{array}{l}1.08 \\
1.66\end{array}$ & 137 & $\begin{array}{l}0.17 \\
0.19\end{array}$ & 0.43 & 0.95 & 1.94 & 12 & 1.28 & 0.93 & 0.26 & 0.31 & 0.68 & 1.68 \\
\hline & & & & & & & 7 & 1.54 & 0.63 & 0.29 & 0.28 & 0.62 & 1.00 \\
\hline
\end{tabular}

TABLE 2. - Small boulder ( $<2 \mathrm{t}$ ) attributes with corresponding Hs estimates using Pignatelli et al.'s (2009) equations. Data of significance in the text refers to the subaerial blocks shifted by lessermagnitude storm waves. Sa $=$ subaerial setting. 


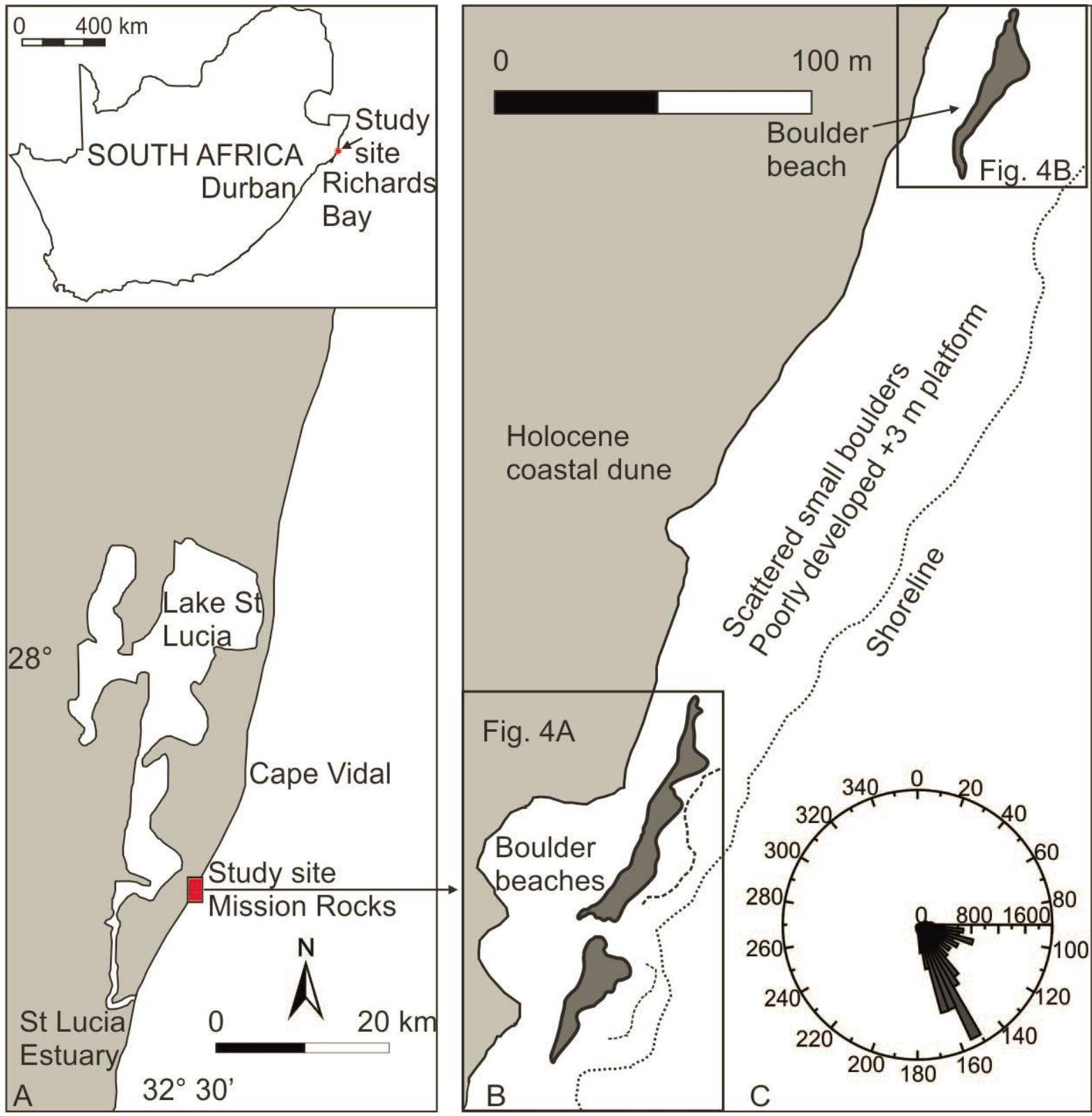

FIG. 1.-A) Locality map detailing the Mission Rocks area relative to Lake St Lucia. B) Enlarged locality map detailing boulder beach localities (depicted as mass distribution in Fig. 4). C) Rose diagram depicting the approaching swell directions and frequencies as measured at Richards Bay $100 \mathrm{~km}$ south of the study area. 


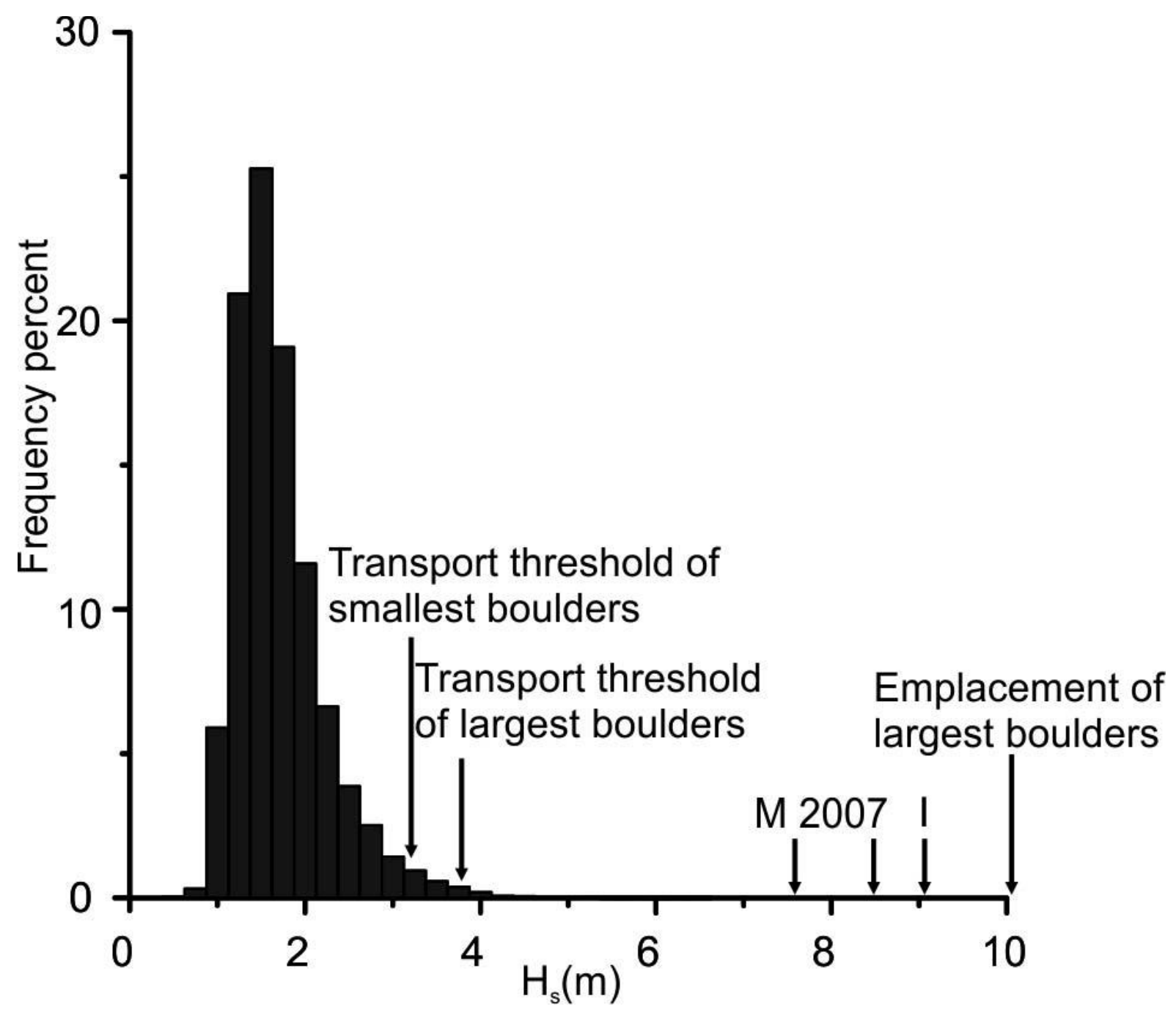

FIG. 2.-Frequency distribution of significant wave height since January 1972. M 2007 are the two swells of the March 2007 Cut Off Low (COL) and I is tropical storm Imboa (data courtesy of the National Ports Authority). Apart from emplacement values, all transport threshold values are calculated using a subaerial pre-transport setting. 


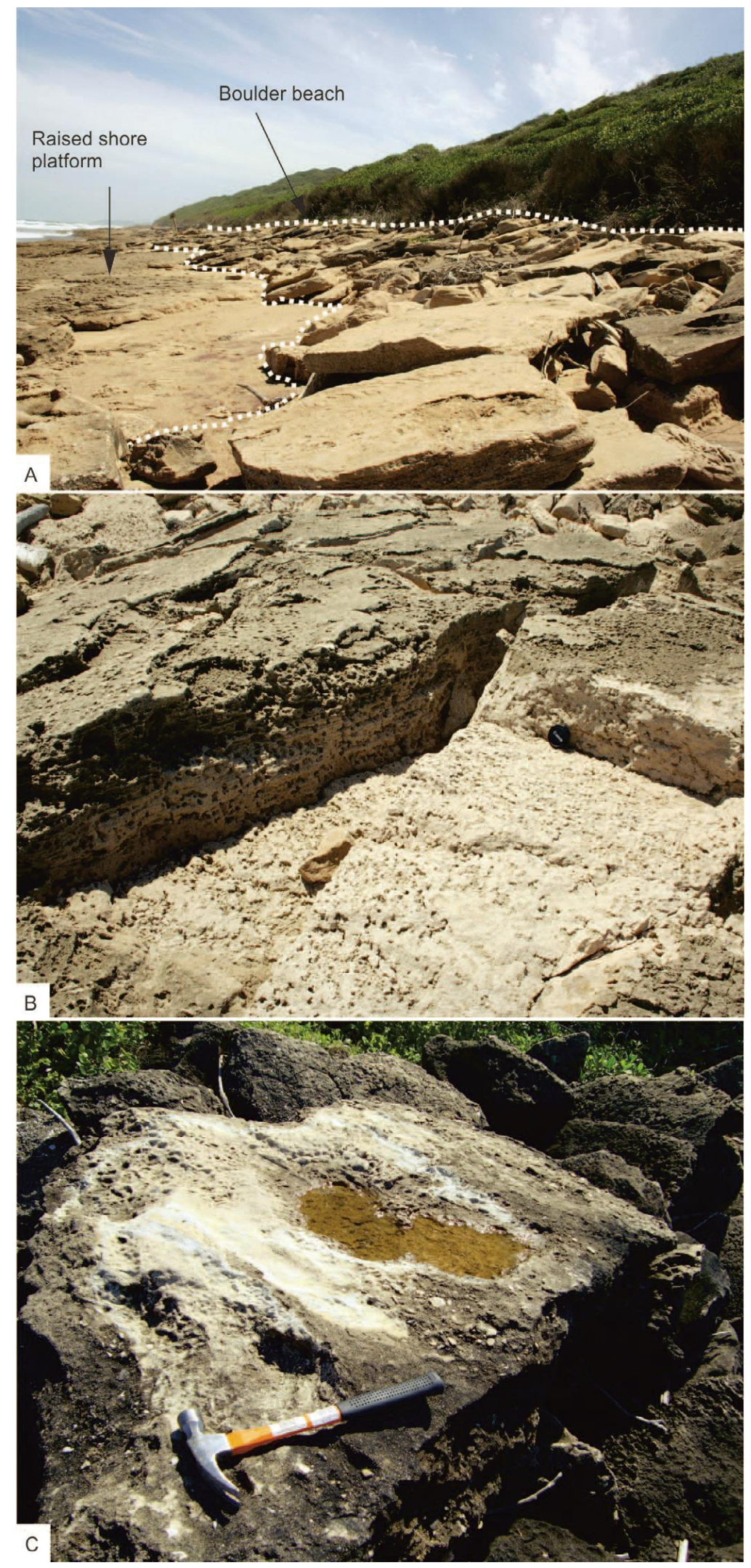

FIG. 3.-A) Boulder beach developed above raised shore platform. Note the boulder-free seaward margin, the imbricated fabric, and the emplacement against the dune cordon. B) Fresh dislocation slot in the upper shore platform surface. C) Abrasion on overturned lower boulder surface. 


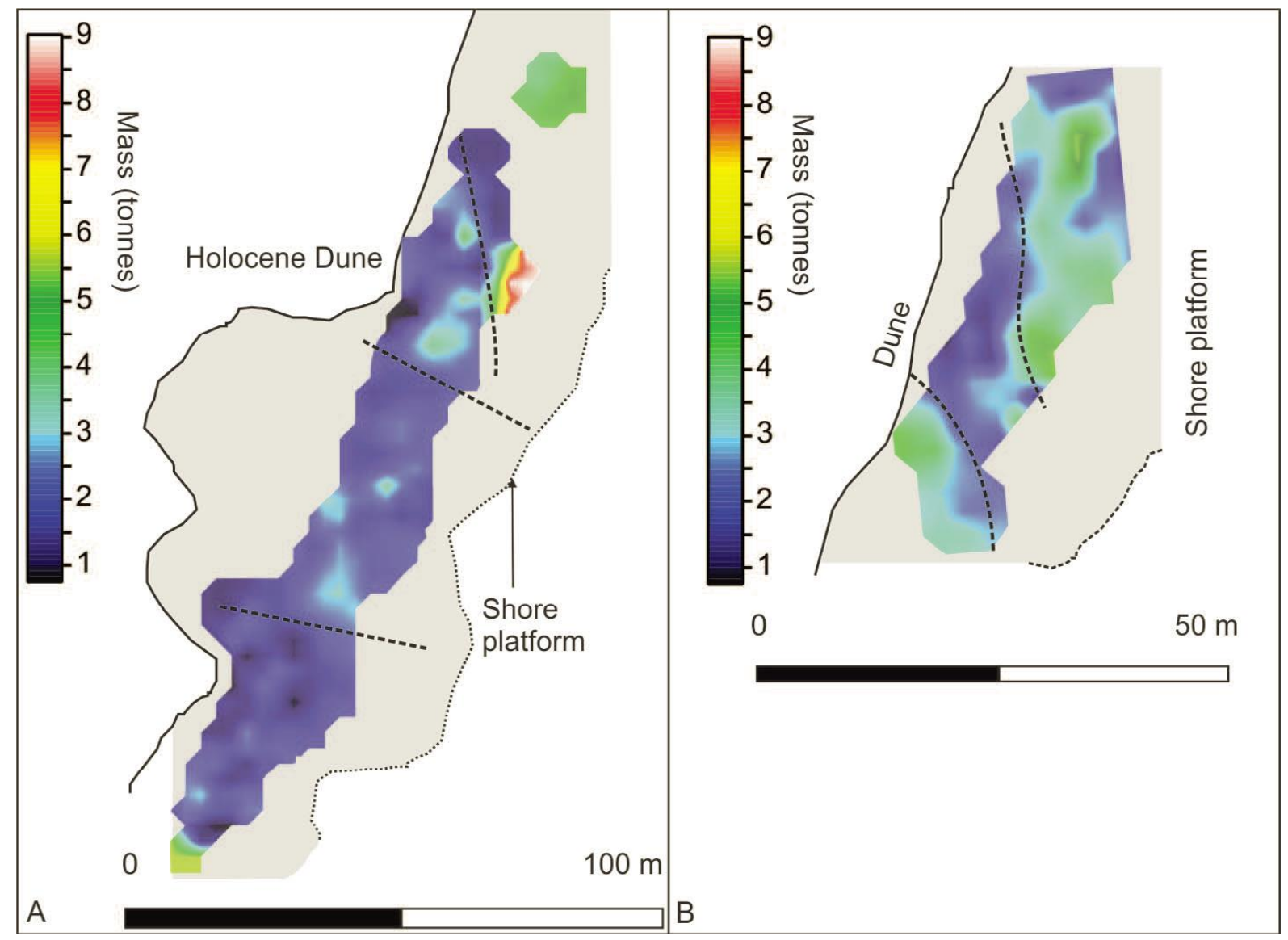

FIG. 4.-Spatial variability of mass in A) the southern boulder beach and B) the northern boulder beach. Note the northward fining trend in each area and development of cell-like features. 